\title{
Ribosomal DNA and chloroplast DNA polymorphisms in a mixed stand of Quercus robur and $Q$ petraea
}

\author{
RJ Petit 1,2, DB Wagner 2, A Kremer 1 \\ 1 INRA, laboratoire de génétique et d'amélioration des arbres forestiers, \\ BP 45, 33611 Gazinet Cedex, France; \\ 2 Department of Forestry, University of Kentucky, Lexington, KY 40546-0073, USA
}

\begin{abstract}
Summary - More than 70 trees belonging to the morphologically distinguishable species Quercus robur $L$ and Quercus petraea (Matt) Liebl were sampled in a mixed stand located in western France. The ribosomal DNA repeat was characterized by a high level of length polymorphism; while chloroplast DNA in our sample was nearly fixed at 2 previously identified polymorphic regions. Overall, very little differentiation was found between species using both markers. The implications for our understanding of this complex of species are discussed.
\end{abstract}

Quercus petraea / Quercus robur / gene flow / diversity / sympatry

Résumé - Polymorphisme de l'unité ribosomique et de l'ADN chloroplastique dans une futaie mixte de chênes pédonculé et sessile. Plus de 70 chênes des 2 espèces Quercus robur $L$ et Q petraea (Matt) Liebl, ont été échantillonnés dans une parcelle de régénération située dans louest de la France. Nous avons étudié le polymorphisme de longueur de l'unité ribosomique ainsi que le polymorphisme de l'ADN chloroplastique. La région codant pour les gènes ribosomiques est très variable. Au contraire, les 2 régions de I'ADN chloroplastique étudiées sont pratiquement monomorphes. La différenciation interspécifique pour ces deux marqueurs est négligeable. Les implications de ces résultats pour notre compréhension de ce complexe d'espèces sont discutées.

Quercus petraea / Quercus robur / flux de gènes / diversité / sympatrique 


\section{INTRODUCTION}

Molecular markers have already provided biologists with an impressive amount of taxonomic data. However, recent studies of chloroplast DNA (CPDNA) variation in plants indicate that some species may share identical cpDNA genotypes (Rieseberg and Soltis, 1991). In the genus Quercus, we have shown that some European white oaks share their cpDNA genotypes and that the pattern of cpDNA variation is primarily geographic, regardless of the species sampled (Kremer et al, 1991). Wittemore and Schaal (1991) found similar results in American white oaks. They also showed that ribosomal DNA polymorphisms could be used to identify some oak species. In these 2 studies, sample sizes per population were low. We have therefore sampled more than 70 trees in a mixed oak stand and analyzed both molecular markers, in order to study intrapopulation and interspecific diversity.

\section{MATERIALS AND METHODS}

\section{Sampling}

A full description of the stand is given in the chapter by Bacilieri et al. This 4-ha stand is located in the Petite Charnie Forest near Le Mans in western France. In order to regenerate the stand before the final harvest, 426 trees of both species had been left by the foresters. Individual trees were sampled for our study in the pure Quercus petraea zone, in the pure $Q$ robur zone and in the mixed $Q$ robur/Q petraea zone. Species identification was based on several morphological markers as explained by Bacilieri et al (1992).

\section{DNA extraction and analysis}

The method of total DNA extraction and analysis of $\mathrm{cpDNA}$ variation has been described previously (Kremer et al, 1991). Adult-tree DNA was ex- tracted from young leaves taken from flushing buds on branches collected in winter and forced in the greenhouse later in the spring. DNA was also extracted from leaves of seedlings germinated in the greenhouse. After digestion of the DNA by endonucleases, repetitive DNA fragments were revealed by ethidium bromide staining of $0.9 \%$ agarose gels after $36-48 \mathrm{~h}$ of migration at $1 \mathrm{~V} / \mathrm{cm}$. Negatives of the gels were taken under UV illumination at $254 \mathrm{~nm}$. Two chloroplast DNA polymorphisms were studied using the restriction endonucleases HindII and Cfol. Polymorphic fragments were verified as chloroplastic by comparison with Southern (1975) blots using cpDNA probes (fragments of the cpDNA of Petunia hybrida digested by Pst (Palmer et al, 1983)). Similarly, we found that Hindll-digested rDNA fragments could also be detected directly by ethidium bromide staining. Two non-overlapping gel zones, named rRNA1 and rRNA2 (fig 1) had fragments which hybridized with the complete rDNA repeat of wheat (pTA 71, cf Gerlach and Bedbrook, 1979). We present here the results of the polymorphism observed in the $10 \mathrm{~kb}$ region (rRNA1).

\section{Measurement and scoring of the rDNA repeat polymorphisms}

Negatives were scanned using a laser densitometer. By comparison with a commercially available size marker ( $1 \mathrm{~kb}$ ladder, Bethesda Research Laboratories), the sizes of several monomorphic chloroplast fragments were estimated using the procedure described by Schaffer and Sederoff (1981). These fragments were then used as natural internal markers in each lane to estimate the sizes of polymorphic rDNA tragments. Indeed, the presence of size markers within a lane enables a more accurate estimate of fragments in that lane than in other lanes, since there is often at least a slight shift among lanes, caused, for example by unequal amounts of DNA present in each lane or by smiling effects.

\section{RESULTS}

\section{CPDNA}

Seventy-two individuals (adults or seedlings from different mother trees) were 


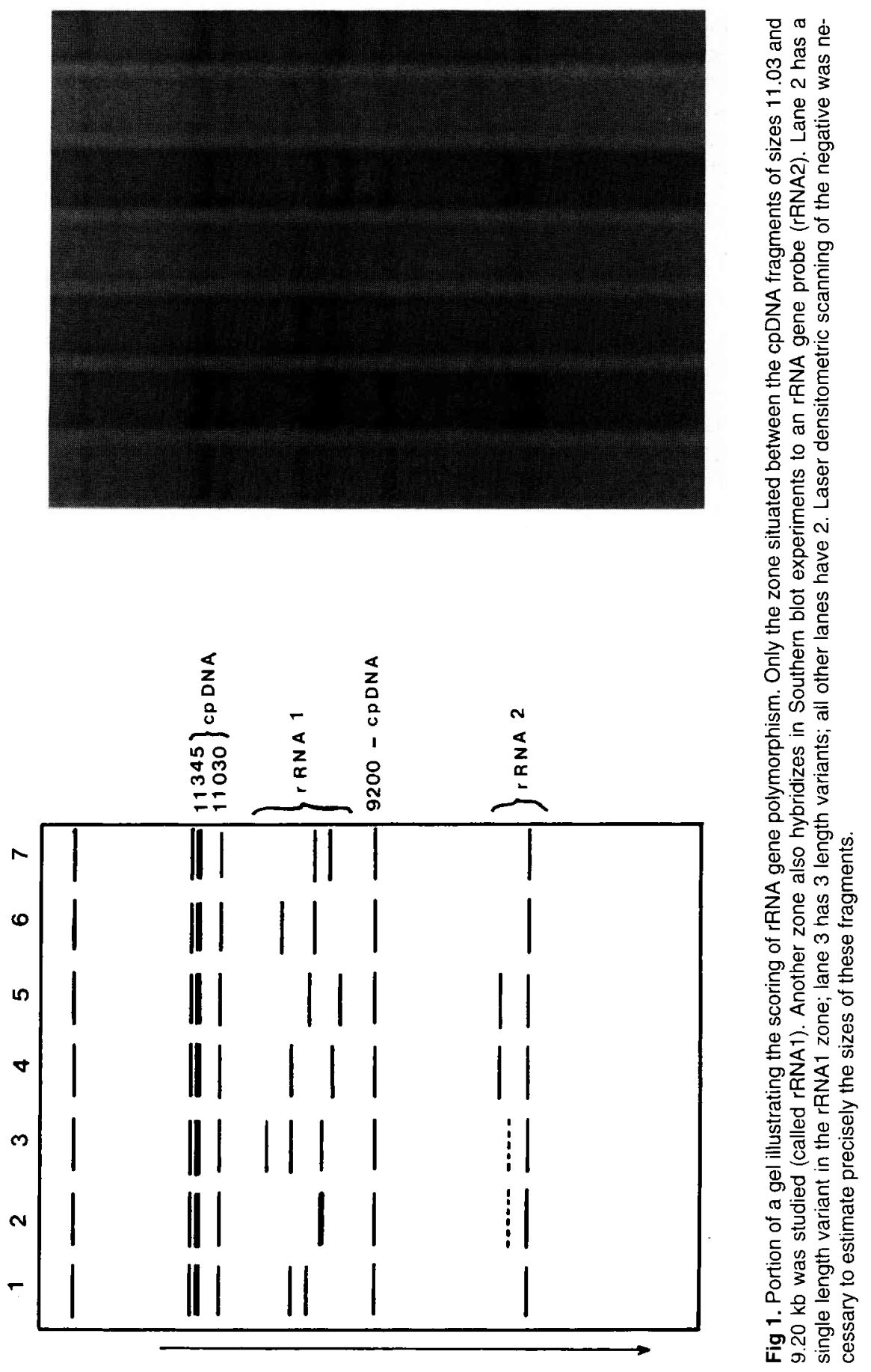


analyzed: 48 of Quercus petraea and 24 of Quercus robur. Seventy-one had the same genotype (with Hindll: variant $5.8 \mathrm{~kb}$; with Cfol: variant $4.3-4.5 \mathrm{~kb}$ ). A single $Q$ petraea individual had the Hindlll variant 2.6$3.2 \mathrm{~kb}$ and the $C f o l$ variant $4.3-4.5 \mathrm{~kb}$.

\section{rDNA}

Twenty-one adult trees and 8 seedlings (from seeds collected from 8 different mother trees) of Quercus robur and 29 adult trees and 12 seedlings (also from seeds collected on different trees) of Quercus petraea were analyzed. The sizes of the variants ranged from 10.24 to $9.46 \mathrm{~kb}$. In order to compare the species, we pooled the results from the adult trees and seedlings. There were 27 individuals $(38.6 \%)$ with 1 band, $42(60 \%)$ with 2 bands and a single seedling (1.4\%) with 3 bands. Since we have preliminary results from controlled crosses indicating that these length variants behave as alleles of a single gene locus (Petit, unpublished data) and in order to estimate the length variant frequencies, length variants present in single-banded individuals were given a weight of 2 (ie, these individuals were considered homozygous). Frequency distributions are given in figure 2 for Quercus robur and in figure 3 for $Q$ petraea. A G-test of comparison of the species with 7 variant classes (by pooling the smaller and larger, less frequent, variants) was nonsignificant at the $5 \%$ probability level $(d f=$ $6, P=0.19)$. We therefore pooled the 70 individuals of both species to calculate the unbiased gene diversity (0.829) and its standard deviation (0.016) using Nei and Roychoudhury's (1974), equations 2 and 12.

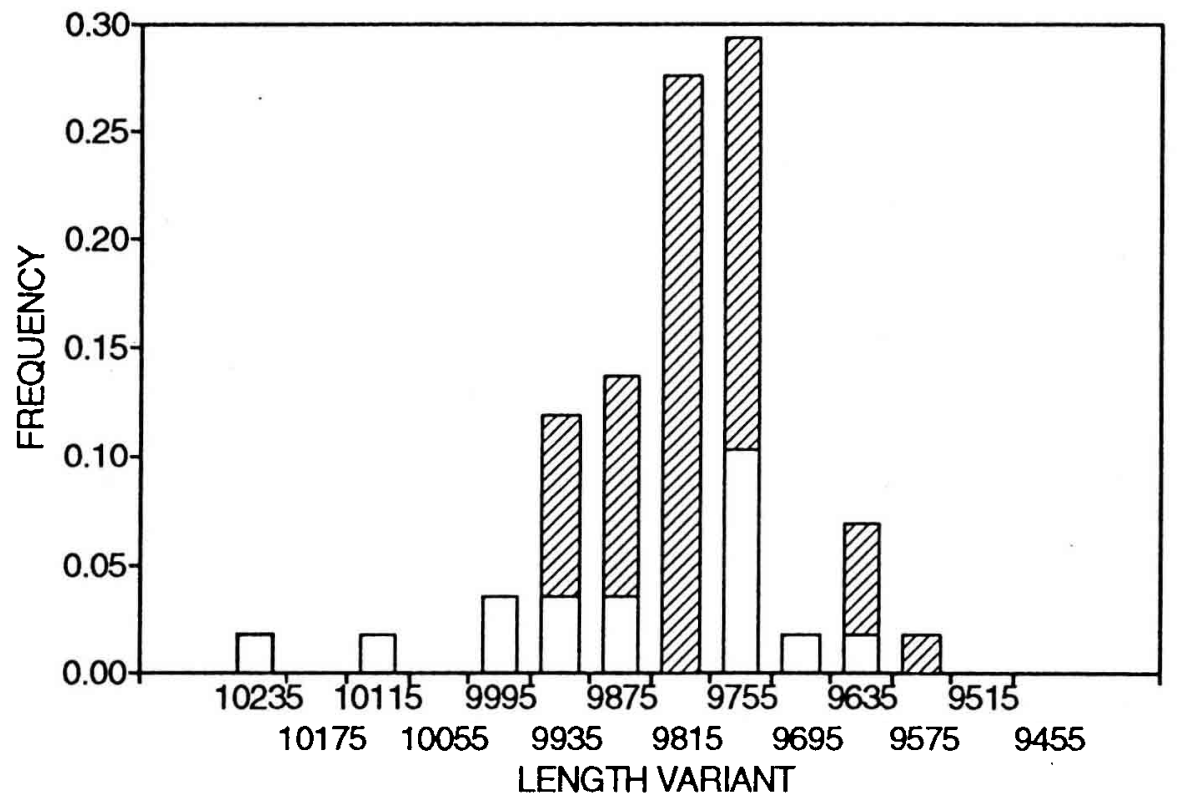

\section{SEEDLINGS WIIA ADULTS}

Fig 2. Length variant frequencies of the rRNA unit in the Petite Charnie stand: Quercus robur. 


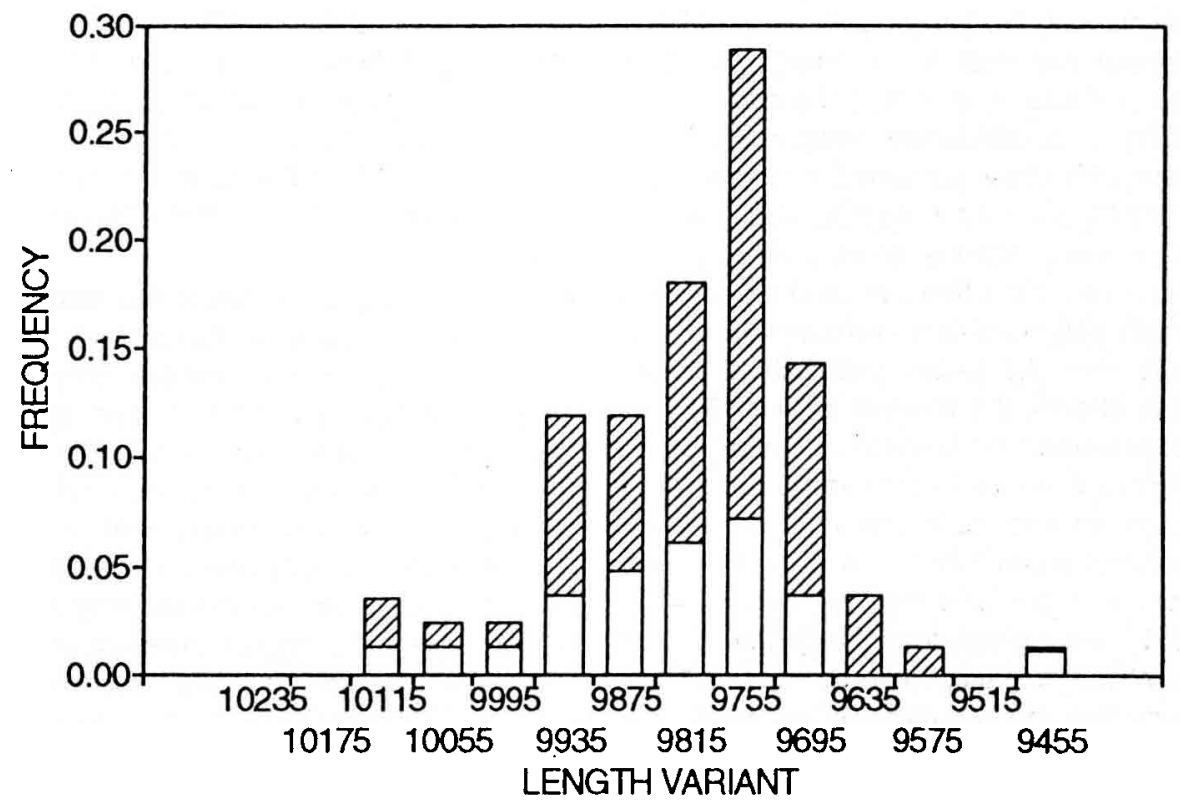

\section{SEEDLINGS UID ADULTS}

Fig 3. Length variant frequencies of the rRNA unit in the Petite Charnie stand: Quercus petraea.

\section{DISCUSSION}

A high level of total diversity, but a low level of intrapopulation diversity (only $8.8 \%$ of the total) was found for cpDNA polymorphisms in a previous study (Kremer et al, 1991). This result was obtained with a large number of populations but a small sample size per population. Therefore, the results obtained in the present study, which confirm that some populations can indeed be almost fixed for a single cytotype, support our initial sampling procedure for the study of cpDNA diversity and differentiation in oaks: a large number of populations with a limited number of individuals rather than the reverse. (Clearly, such a sampling scheme is not appropriate for nuclear genes.) Note that, despite the small number of chloroplast polymorphisms studied, the high level of differentiation found in our first study is representative of any cpDNA polymorphism if recombination does not occur in the chloroplast genome. In some situations, however, an important local mixing of two cpDNA genotypes was observed, and the analysis of $\mathrm{cpDNA}$ genetic structure of such populations would be of great interest. The absence of cytoplasmic differentiation between species found in the present study also reflects a more general trend (Kremer et al, 1991).

The level of diversity of the rDNA repeat, on the other hand, is extremely high (0.829). The average value of intrapopula- 
tion diversity for isozymes in oaks is 0.134 (Kremer and Petit, this volume). For Quercus petraea it is 0.277 (Kremer et al, 1991). It is difficult to compare our estimate with other published measurements of rDNA diversity in natural plant populations, since sample sizes varied greatly. Moreover, it is often not reported whether length polymorphism corresponds to 1 or more loci. As Learn and Schaal (1987) have shown, the amount of diversity cannot at present be predicted from characteristics such as life-history traits; this diversity ranges from no length variation at all to extreme cases with up to 20 variants per plant in Vicia faba (Rogers and Bendich, 1987) and a great deal of within-population variation. In oaks, Bellarosa et al (1990) found that the variability of the rDNA units was low for Quercus suber and $Q$ trojana. Whittemore and Schaal (1991) state that for American white oaks, "appreciable length variation was observed. All plants examined contained repeat types between 9 and $10.5 \mathrm{~kb}$ in length, each individual having from one to three repeat types in this length range. Variation within this range is high within populations, and these length variants are not useful for comparing different species or localities." They did, however find a shorter repeat type distinctive of a group of species. In contrast, a shorter repeat is also present in the oaks we studied (rRNA2 region) but it is not specific to one of them.

The absence of significant rDNA differences between the species in the mixed oak stand was unexpected, because tandemly repeated DNA sequences, such as the rRNA gene unit, are very often considered to be excellent species markers. Dover (1983) stated that molecular drive in repeated gene families may lead to a cohesive mode of species evolution, ie, species may become differentiated more quickly than by drift alone. Moreover, in the same population, Bacilieri et al (this volume) found large differences in allelic frequencies between the species for most allozymes studied, especially in the adult stage. Even though our sample size is smaller, it is clear that many allozymes are more differentiated than the rRNA gene region.

How should we interpret this discrepancy among nuclear markers, and among some nuclear markers and the cytoplasmic markers? Spirito (1990) studied theoretically the reduction of neutral gene flow caused by a single selected gene in plants. It is obvious from his results that, in allogamous plants, neutral genes unlinked to the selected gene are easily exchanged even if the selection is high. Rieseberg and Soltis (1991) present empirical evidence indicating that cytoplasmic gene flow may be high even when nuclear gene flow is very low. This requires that the various cytotypes have similar selective values in the species nuclear backgrounds. Information about selective pressures (ie, disruptive selection) that preserve species integrity despite high gene flow are sorely needed to improve our understanding of this complex of species.

\section{REFERENCES}

Bacilieri R, Roussel G, Ducousso A (1993) Hybridization and mating system in a mixed stand of sessile and pedunculate oak. Ann Sci For 50 (suppl 1), 122s-127s

Bellarosa R, Delre V, Schirone B, Maggini F (1990) Ribosomal RNA genes in Quercus spp (Fagaceae). Plant Syst Evol 172, 127139

Dover G (1982) Molecular drive: a cohesive mode of species evolution. Nature 299, 111 117

Kremer A, Petit RJ (1993) Gene diversity in natural populations of oak species. Ann Sci For 50 (suppl 1), 186s-202s

Kremer A, Petit RJ, Zanetto A, Fougère V, Ducousso A, Wagner DB, Chauvin C (1991) Nu- 
clear and organelle gene diversity in $Q$ robur and $Q$ petraea. In: Genetic Variation in European Forest Trees (Müller-Starck G, Ziehe $M$, eds) Sauerländer's Verlag, Frankfurt-amMain, 141-166

Gerlach WL, Bedbrook JR (1979) Cloning and characterization of ribosomal RNA genes from wheat and barley. Nucleic Acids Res 7, 1869-1885

Learn GH, Schaal BA (1987) Population subdivision for ribosomal DNA repeat variants in Clematis fremontii. Evolution 41, 433-438

Nei M, Roychoudhury AK (1974) Sampling variances of heterozygosity and genetic distance. Genetics 73, 379-390

Palmer JD, Shields CR, Cohen DB, Orton TJ (1983) Chloroplast DNA evolution and the origin ot the amphidiploids Brassica species. Theor Appl Genet 65, 181-189
Rieseberg LH, Soltis DE (1991) Phylogenetic consequences of cytoplasmic gene flow in plants. Evol Trends Plants 5, 65-84

Rogers SO, Bendich AJ (1987) Heritability and variability in ribosomal RNA genes of Vicia faba. Genetics 117, 285-295

Schaffer HE, Sederoff RR (1981) Improved estimation of DNA fragments from agarose gels. Anal Biochem 115, 113-122

Southern EM (1975) Detection of specific sequences among DNA fragments separated by gel electrophoresis. J Mol Biol 98, 503517

Spirito $F(1990)$ The reduction of neutral gene flow caused by a selected gene in plant population models. Theor Popul Biol 38, 113-124

Whittemore AT, Schaal BA (1991) Interspecific gene flow in sympatric oaks. Proc Natl Acad Sci USA 88, 2540-2544 